УДК 349.6

DOI https:/ / doi.org/10.32837/yuv.v0i3.1908

Ю. Краснова,

доктор юридичних наук, доцент,

доцент кафедри аграрного, земельного та екологічного права

імені академіка В.З. Янчука

Національного університету біоресурсів і природокористування України

\title{
ПРАВОВІ ЗАСАДИ ВИЗНАЧЕННЯ ДЖЕРЕЛ ТА ОБ'ЄКТІВ ШКІДЛИВОГО ВПЛИВУ ВОДНОГО ТРАНСПОРТУ УКРАЇНИ НА ДОВКІЛЛЯ
}

3 моменту винаходу людством механічних засобів пересування, які в сучасних умовах визначаються загальним поняттям «транспорт», починає формуватися одна з основних галузей суспільного господарювання, що є важливою складовою частиною міжлюдських стосунків. Сам процес перевезень не виробляє нового продукту, однак в межах його здійснення з'являється сполучна ланка між підприємствами, установами, організаціями, іншими господарюючими суб'єктами, що сприяє функціонуванню інших галузей економіки, розв'язанню соціальних завдань, раціональному та гнучкому використанню виробничих сил, забезпечуючи обороноздатність країни тощо [1, с. 6].

Відповідно до Закону України «Про транспорт» від 10 листопада 1994 року [2] транспорт визначено як сукупність механічних засобів перевезень, виробничо-технологічного комплексу, організацій і підприємств, призначених для забезпечення потреб суспільного виробництва і населення країни в перевезеннях у внутрішньому та міжнародному сполученнях і надання інших транспортних послуг усім споживачам, які здійснюються на автомобільному, залізничному, повітряному, морському, річковому, міському електротранспорті та трубопровідному транспорті.

Одним зі складників єдиної транспортної системи України $€$ водний транспорт, який, об'єднуючи такі потужні ланки як морський і річковий транспорт, є комплексною галуззю, призначеною задовольняти потреби населення та суспільного виробництва у перевезеннях водними шляхами сполучення (як природними (океани, моря, річки, озера), так і штучними (канали, водосховища). Водному транспорту притаманні певні властивості, які виявляються через основні категорії водного транспорту, наділені певним юридичним статусом. Як уже зазначалося, водний транспорт складається 3 двох окремих елементів: морського та річкового транспорту.

Згідно Закону України «Про транспорт» морський транспорт - це транспорт, до складу якого входять підприємства морського транспорту, що здійснюють перевезення пасажирів і вантажів, порти і пристані, судна, судноремонтні заводи, морські шляхи сполучення, а також підприємства зв'язку, промислові, торговельні, будівельні і постачальницькі підприємства, навчальні заклади, заклади охорони здоров'я, фізичної культури, науково-дослідні, проектно-конструкторські організації та інші підприємства, установи та організації незалежно від форм власності, які забезпечують роботу морського транспорту.

Річковий транспорт - транспорт, до складу якого входять підприємства річкового транспорту, що здійснюють перевезення пасажирів і вантажів, 
порти і пристані, судна, суднобудівно-судноремонтні заводи, ремонтно-експлуатаційні бази, підприємства шляхового господарства, а також підприємства зв'язку, промислові, торговельні, будівельні та постачальницькі підприємства, навчальні заклади, заклади охорони здоров'я, фізичної культури та спорту, культури, проектно-конструкторські організації та інші підприємства, установи й організації незалежно від форм власності, які забезпечують роботу річкового транспорту.

Всі підприємства та організаціі річкового транспорту, які здійснюють та забезпечують перевезення внутрішніми судноплавними річковими шляхами вантажів, пасажирів, багажу, пошти та надають інші транспортні послуги з використанням суден, а також малі судна та бази для ї стоянки, об'єднуються в одну ланку - внутрішній водний транспорт, який є підгалуззю суспільного виробництва. Такі види водного транспорту в Україні представлені судами державних, акціонерних і приватних судноплавних компаній на узбережжі Чорного, Азовського морів, річках Дунай, Дніпро і Південний Буг.

Як і будь-яка інша діяльність людини, водний транспорт використовує у своїй діяльності різні природні ресурси (вода, атмосферне повітря, земля). Тому сфера правового регулювання діяльності водного транспорту розповсюджується й на екологічне право та законодавство, а правовідносини набувають природоресурсного характеру.

Вступаючи у природоресурсні правовідносини, суб'єкти господарської діяльності на водному транспорті України одночасно стають і суб'єктами природоохоронних правовідносин, які виникають у зв'язку з відведенням у навколишнє природне середовище викидів і скидів забруднюючих речовин, розміщенням відходів, фізичних i біологічних впливів, які утворюються в процесі діяльності водного транспорту. Такі особливості діяльності цього виду транспорту зумовлюють врахування вимог, встановлених екологічним законодавством для попередження виникнення небезпеки від таких впливів на навколишнє природне середовище та життя і здоров'я людей.

Відносини, які при цьому виникають, набувають характеру природоохоронних (середовищеохоронних) 3 точки зору здійснення при цьому охорони земель, вод, атмосферного повітря, інших природних ресурсів і комплексів, а також відносин правового забезпечення екологічної безпеки громадян з точки зору охорони i захисту їх конституційного права на безпечне для життя та здоров'я довкілля (ст. 50 Конституції України).

У науці екологічного права така група правовідносин визначається як антропоохоронна [3, с. 15], абсолютна [4, с. 46] по своїй важливості, а сфера, у межах якої вона формуються та регулюються, - як правове регулювання екологічної безпеки, правове забезпечення екологічної безпеки, право екологічної безпеки тощо. Тому особливої актуальності набуває питання дослідження існуючих видів впливу водного транспорту на довкілля 3 метою подальшого визначення правових механізмів їх запобігання.

Зі змісту ст. 56 Закону України «Про охорону навколишнього природного середовища» від 25 червня 1991 року [5], яка визначає загальні правові засади забезпечення екологічної безпеки транспортних та інших пересувних засобів і установок, в тому числі суден, випливає, що саме щодо цих засобів необхідно розробляти і здійснювати комплекс заходів по зниженню токсичності та знешкодженню шкідливих речовин, які містяться у відпрацьованих викидах i скидах транспортних засобів, переходу на менш токсичні види енергії й пального, додержання режиму експлуатації транспортних засобів 
та інші заходи, спрямовані на запобігання й зменшення викидів і скидів у навколишне природне середовище забруднюючих речовин і додержання встановлених рівнів фізичних впливів. Схоже за змістом положення міститься й у ст. 28 Кодексу торговельного мореплавства України [6], згідно з яким всі судна, які допускаються до плавання, мають відповідати екологічним вимогам.

Особливості викидів, скидів забруднюючих речовин і здійснення фізичних впливів водними суднами, іншими джерелами цієї галузі на довкілля залежать від режиму їх експлуатації. Не дарма О.C. Iоффе писав: «Транспортний засіб, поки не буде приведений до руху зусиллями людини, не містить у собі нічого такого, що не піддається контролю, де момент підконтрольності має відношення не до речей або сил природи самих по собі, а до процесу і наслідків діяльності людини, яка призводить їх до руху» [7, с. 418].

На його думку, особливість техніки в тому і полягає, що, використовуючи іi, людина не завжди має можливість повністю проконтролювати процес і можливі наслідки своєї діяльності. В екологічному аспекті такий підхід відіграє важливу роль, адже основна частина негативних впливів на навколишнє природне середовище на водному транспорті утворюються саме в процесі експлуатації відповідної техніки - суден, які утворюють викиди та скиди забруднюючих речовин, шумові впливи на довкілля від роботи їх двигунів тощо, оскільки виникнення таких впливів пов'язане не лише із застосуванням людиною щодо таких суден свого вміння керувати ними, а й у застосуванні при цьому спеціальних властивостей самих транспортних засобів, а також засобів забезпечення їх руху - пально-мастильних матеріалів, стисненого повітря, ядерного палива тощо.

При цьому враховується визначення в чинному законодавстві кате- горії «судно», під яким розуміють самохідні або несамохідні плавучі споруди, що використовується в цілях судноплавства, у тому числі судна змішаного (ріка-море) плавання, пороми, вонботи, днопоглиблювальні й дноочисні снаряди, плавучі крани, населені підводні апарати і глибоководні водолазні комплекси, плавучі бурові установки тощо [8].

Залежно від призначення і технічних характеристик судна i кораблі поділяються на класи, а в межах класів - на підкласи з урахуванням дальності плавання, тоннажу або спеціалізації. Регістрові судна класифікують за такими ознаками:

- за призначенням: 1) транспортні (пасажирські: морські лайнери, круїні судна); 2) вантажні: ролкери, балкери, танкери, універсали; вантажопасажирські; 3) промислові: рибодобувні i рибопереробні: сейнери, траулери, китобійні судна, дрифтери); 4) науково-дослідні (експедиційні, гідрографічні); 5) навчальні та спортивні; 6) спеціальні (лоцманські, плавучі маяки, водолазні, пожежні); 7) судноремонтні (плавмайстерні, плавучі крани, плавучі доки); 8) службові (криголами, буксири, штовхачі, роз”іздні); 9) рятувальні: бази, боти, понтони, буксири); 10) технічні: грунтовози, днопоглиблювачі;

- за районом плавання: а) морські (дальнього, необмеженого, прибережного плавання, рейдові); б) внутрішнього плавання (річкові, озерні); в) змішаного плавання (ріка-море);

- за типом головного двигуна (енергетичної установки): 1) теплоходи (двигун внутрішнього згоряння); 2) пароплави (парова машина); 3) турбоходи (парова турбіна); 4) газотурбоходи (газова турбіна); 5) дизель-електроходи (електричні установки, які отримують енергію від двигуна внутрішнього згоряння); 6) електроходи (електричні установки, які отримують енергію від турбіни); 7) атомоходи (атомна енергетична установка); 
- за способом руху: а) водовитісняючі; б) підводні; в) 3 динамічними принципами підтримки (глісери, на підводних крилах, на повітряній подушці);

- за способом руху і типом рушія: а) самохідні: гребні, вітрильні та моторні судна (гвинтові, 3 крильчастим, водометним або роторним рушієм); б) несамохідні судна (баржі);

- за матеріалом корпусу: сталеві, з легких сплавів, пластмасові, дерев'яні, залізобетонні, композитні тощо.

Таким чином, всі водні судна можна поділити за такими критеріями їх впливу на довкілля на: 1) водні судна, які не чинять шкідливого впливу на довкілля (гребні та вітрильні судна, плавучі маяки); 2) водні судна, які чинять або можуть спричинити хімічний та/або фізичний шкідливий вплив на довкілля, де під фізичним впливом розуміється як шумовий, так і радіаційний вплив (всі інші зазначені вище види водних суден).

Під хімічним забрудненням довкілля в цьому випадку розуміється не лише забруднення атмосферного повітря вихлопними газами водних транспортних засобів, а й здійснення під час їх використання скидів забруднюючих речовин, де під скидами розуміється будь-яке витікання, розлиття, зливання, спорожнення, що здійснюють із судна у воду, незалежно від того, якими причинами це зумовлено, відносно шкідливих речовин або стоків, які містять такі речовини (п. 1.3 Наказу Міністерства транспорту України від 10 квітня 2001 року № 205 «Про затвердження Правил реєстрації операцій зі шкідливими речовинами на суднах, морських установках і в портах України») [9].

Скиданню в такому випадку підлягає:

1) сміття - всі види продовольчих, побутових і експлуатаційних відходів (крім свіжої риби та їі залишків), що утворюються в процесі нормальної експлуатації судна і підлягає постійному або періодичному вилученню;
2) стічні води - стоки та інші відходи з усіх типів туалетів, а також шпигатів, які знаходяться у загальних туалетах; стоки з раковин, ванн, душових і шпигатів, що знаходяться в медичних приміщеннях (амбулаторіях, лазаретах); стоки 3 приміщень, в яких утримують живих тварин; інші стоки, якщо вони змішані з переліченими вище;

3) шкідлива речовина - будь-яка речовина, яка, потрапляючи у море, здатна створити небезпеку для здоров'я людей, завдати шкоди живим ресурсам, морській флорі і фауні, порушити природну привабливість моря як місця відпочинку або завадити іншим видам правомірного використання моря і включає будь-яку речовину. До шкідливих речовин у цьому випадку віднесені нафта, нафтові залишки, відпрацьовані мастила, нафтовмісні лляльні і баластні води, стічні води, сміття та залишки хімічних речовин, які перевозять на суднах наливом, навалом і в упаковці.

Відповідно до Постанови Верховної Ради України від 5 березня 1998 року № 188 «Про основні напрями державної політики України у галузі охорони довкілля, використання природних ресурсів і забезпечення екологічної безпеки» [10] такі скиди значно погіршують екологічний стан водних об'єктів, зокрема моря, особливо в припортових зонах, що й стало одним із факторів визнання будівництва морських і річкових портів екологічно небезпечним видом діяльності (п. 7 ч. 2 ст. 3 Закону України «Про оцінку впливу на довкілля» від 23 травня 2017 року [11]). Ці положення побіжно враховані і в Законі України «Про морські порти України» [12].

Наступним фактором визнання екологічно небезпечним будівництва морських і річкових портів $є$ те, що ї основна мета - це обслуговування суден і пасажирів, проведення вантажних, транспортних та експедиційних робіт, а також інших пов'язаних із цим видів господарської діяльності (ст. 1 Закону України «Про морські 
порти України»).У зв'язку 3 цим в межах таких портів або поряд із ними здебільшого розміщують спеціалізовані причали, пристані, вокзали, будівлі, споруди, устаткування, об'єкти загальнопортового і комплексного обслуговування флоту; гідротехнічні споруди і засоби навігаційної обстановки, судноремонтні заводи, склади, радіоцентри, ремонтно-експлуатаційні бази, судноверфі, відстійно-ремонтні пункти, склади, матеріально-технічні бази, інженерні мережі, інші об'єкти, які забезпечують роботу водного транспорту та можуть спричинити забруднення навколишнього природного середовища і погіршити здоров'я людей.

Для багатьох виробничих процесів у портах і на судноремонтних підприємствах характерним є значне використання різного роду шкідливих речовин, які використовуються як для обслуговування транспортних засобів, так і для інших експлуатаційних потреб. Крім того, для таких об'єктів притаманна велика запиленість. Біологічна активність пилу визначається іï хімічним складом. Пил, до складу якого входить діоксид кремнію, при тривалому вдиханні може призводити до низки професійних захворювань, насамперед пневмоконіозу - групи захворювань легенів, а також захворюванням очей і шкіри. Випари шкідливих речовин у вигляді аерозолів, пари, туману (пари молібдену, хрому, літію, сірчаної та соляної кислот), а також відпрацьовані гази проникають в організм людини через легені, шкіру, шлунково-кишковий тракт і викликають професійні захворювання та отруєння.

Значну екологічну небезпеку в морських і річкових портах становлять і трюмні осадові відкладення, підсланеві (лляльні) води, які утворюються при експлуатації пасажирських, вантажоперевізних, риболовних суден і нафтоналивних танкерів. Вони утворюються і скупчуються на самому дні трюму будь-якого судна.
Підсланеві води («мертві запаси», нафтошлами) - складні суміші стоків, до складу яких входять різні нафтопродукти і механічні домішки.

Концентрація забруднюючих компонентів дуже варіюється. У результаті старіння осадових відкладень відбувається «вимивання» легких фракцій, випаровування летючих речовин, окислення і осмолення вуглеводнів нафтопродуктів. Крім того, присутні в лляльних стоках смоли i асфальтени утворюють стійкі до руйнування колоїдно-міцелярні системи. Обробка та утилізація лляльних вод - одне $з$ найважчих завдань очищення стічних вод.

Підсланеві води віднесені до другого класу екологічної небезпеки та включені в один список із такими речовинами як сірчана кислота, електроліти, цементний пил та інше [13]. Потрапляння підсланевих вод у водойми призводить до хімічного забруднення водного середовища та донних грунтів. Негативний ефект впливу підсланевих вод на іхтіофауну виявляється у погіршенні нересту і скороченні популяцій риб, зниженні їх умовно-рефлекторної діяльності.

Досить часто разом із баластними водами на морських судах відбувається транспортування чужорідних морських організмів [14, с. 21], що $€$ не тільки великою екологічною проблемою, а й проблемою безпеки мореплавання, рибальства та рибництва, сільського господарства, тобто величезною економічною і соціальною проблемою [14, с. 22]. У зв'язку з цим Водний кодекс України від 6 червня 1995 року [15] встановлює єдині для всіх типів морського і річкового транспорту вимоги щодо користування водними об'єктами для потреб водного транспорту (ст. 67 Кодексу).

Зокрема, всі судна та інші плавучі засоби мають бути обладнані ємкостями для збирання лляльних вод, тобто вод із домішками (переважно нафтопродуктів), зібраних у колодязях - ллялах машинних 
відділень судна, та інших забруднених вод, які повинні систематично передаватися на спеціальні очисні споруди для очищення та знезараження. Забороняється заходження в територіальне море суден, які не провели заміну ізольованого баласту i не обладнані цистернами й закритими фановими системами для збирання стічних вод будь-якого походження чи установками для очищення та знезараження цих вод, які відповідають міжнародним стандартам.

3 метою охорони поверхневих водних об’єктів від забруднення і засмічення та збереження водності вздовж річок, морів і навколо озер, водосховищ та інших водойм в межах водоохоронних зон, які складають землі водного фонду, виділяються земельні ділянки під прибережні захисні смуги, а також берегові смуги водних шляхів. Прибережні захисні смуги визначаються Водним кодексом України як природоохоронні території 3 режимом обмеженої господарської діяльності на якій, зокрема, забороняється миття та обслуговування транспортних засобів і техніки, будівництво будь-яких споруд, у тому числі для транспортних потреб тощо (ст.ст. 88-92 Водного кодексу).

На виконання зазначених вище вимог на підзаконному рівні були прийняті Накази Міністерства транспорту та зв'язку України від 13 серпня 2007 року № 694 «Про затвердження Правил запобігання забрудненню із суден внутрішніх водних шляхів Україн» [16] та від 13 червня 2007 року № 2007 року № 491 «Про затвердження Інструкціі щодо процедур прийняття та скидання водного баласту на акваторії річкових внутрішніх водних шляхів України» [17], Наказ Міністерства інфраструктури України від 05 грудня 2016 року № 433 «Про затвердження Інструкції про порядок пломбування в морських портах суднових запірних пристроїв, призначених для скидання забруднюючих речовин і вод, які їх містять» [18], а також Постанова Кабі- нету Міністрів України від 14 квітня 1997 року № 347 «Про затвердження Порядку складання паспортів річок i Порядку встановлення берегових смуг водних шляхів і користування ними» [19].

Самостійний вид впливу водного транспорту на довкілля становить перевезення небезпечних вантажів, оскільки небезпека від такої діяльності може настати лише у випадку настання аварійних ситуацій на транспортних засобах. Правове регулювання такого виду діяльності в Україні здійснюється Законом України «Про перевезення небезпечних вантажів» [20].

В основі правового регулювання екологічної безпеки водного транспорту на національному рівні лежить низка міжнародних угод. До них належать, зокрема, Міжнародна конвенція про запобігання забрудненню моря нафтою 1954 року (Конвенція ОИЛПОЛ 1954 року), Конвенція про запобігання забруднення моря викидами відходів та інших матеріалів 1972 року, Міжнародна конвенція про запобігання забруднення з суден 1973 року з Протоколом 1978 року (МАРПОЛ 73/78), Міжнародна конвенція про цивільну відповідальність за шкоду від забруднення нафтою 1969 року, Конвенція ООН по морському праву 1982 року, Конвенція про захист Чорного моря від забруднення від 21 квітня 1992 року, Міжнародний кодекс морського перевезення небезпечних вантажів 1965 року, Женевська конвенція про цивільну відповідальність за шкоду, заподіяну при перевезенні небезпечних вантажів автомобільним, залізничним і внутрішнім водним транспортом від 1 лютого 1990 року та інші.

Аналізуючи зазначене вище, всі види забруднень навколишнього природного середовища водним транспортом можна поділити на: а) забруднення внаслідок експлуатаційних викидів; б) забруднення внаслідок аварій; в) забруднення внаслідок поховання відходів. 
Таким чином, сфера небезпечного впливу водного транспорту на довкілля досить розгалужена і включає в себе такі види діяльності: 1) будівництво морських і річкових портів; 2) використання, зберігання та транспортування шкідливих (небезпечних) речовин, в тому числі й таких, що приводять у рух або дозволяють експлуатувати морські та річкові судна, пально-мастильних матеріалів, інших небезпечних речовин, небезпечних вантажів; 3) використання спеціальних технічних засобів, необхідних при експлуатації морських і річкових суден, які призводять до утворення фізичних (електромагнітних, іонізуючих) впливів - радіоцентри; 5) скидання небезпечних відходів.

Згідно зі ст. 1187 Цивільного кодексу України [21] діяльність, пов'язана з використанням, зберіганням або утриманням транспортних засобів, механізмів та обладнання, використанням, зберіганням хімічних, радіоактивних, вибухо- і вогненебезпечних та інших речовин тощо, що створює підвищену небезпеку для особи, яка цю діяльність здійснює, та інших осіб, визначається джерелом підвищеної небезпеки.

Запропоновано в національному законодавстві про водний транспорт визначити, що джерелами шкідливого впливу є: 1) використання, зберігання та транспортування шкідливих (небезпечних) речовин, вантажів; 2) проектування, виробництво, експлуатація та обслуговування транспортних засобів як джерел хімічного впливу на довкілля (морських і річкових суден); 3) будівництво морських i річкових портів; 4) використання спеціальних технічних засобів, необхідних при експлуатації морських i річкових суден, які призводять до утворення фізичних (електромагнітних, іонізуючих) впливів; 5) скидання небезпечних відходів.

Шкідливі впливи на водному транспорті створюються об’єктами, якими виступають: 1) небезпечні речовини, відходи, вантажі, які використовуються, утворюються або транспортуються морськими та річковими суднами; 2) морські та річкові судна; склади пально-мастильних матеріалів; радіоцентри та інші об'єкти інфраструктури водного транспорту.

У статmі акцеентується увагана особливостях впливу водного транспорту на довкілля шляхом правового визначення екологічно шкідливих джерел та об’єктів водного mparcnopmy. Ha підставі аналізу сучасного нормативно-правового регулювання екологічної безпеки на водному транспорті з’ясовано, що сфера небезпечного впливу водного mpaнcпорту на довкілля досить розгалужена $i$ включає в себе такі види діяльності (джерела):

1) будівництво, реконструкція, реставрація, капітальний ремонт морських і річкових портів, пристаней для завантаження $i$ розвантаження (за винятком пристаней паромних переправ);

2) використання, зберігання та транспортування шкідливих (небезпечних) речовин, небезпечних вантажів;

3) використання спеціальних технічних засобів, необхідних при експлуатації морських $i$ річкових суден, які призводять до утворення фізичних (електромагнітних, іонізуючих) впливів - радіоиентри;

4) скидання небезпечних відxодів.

Встановлено, що шкідливі впливи на водному транспорті створюються об'єктами, якими виступають: 1) небезпечні речовини, відходи, вантажі, які використовуються, утворюються або транспортуються морськими та річковими суднами; 2) морські та річкові судна; 3) об'єкти інфраструктури водного mparcnopmy.

Правове регулювання таких видів діяльності має здійснюватися в межах механізму правового забезпечення екологічної безпеки, 
який визначається як сукупність державно-правових засобів, спрямованих на регулювання діяльності, спроможної посилювати рівень екологічної безпеки, попередження погіршень екологічної обстановки та виникнення небезпеки для населення й природних систем, локалізацію виявів екологічної небезпеки.

Автор доходить висновку, шьо сучасне вітчизняне законодавство про водний транспорт потребує удосконалення шляхом закріплення прямих правових норм про джерела та об'єкти шкідливого впливу на довкілля.

Ключові слова: водний транспорт, шкідливий вплив, довкілля, джерело впливу, об’єкт впливу.

Krasnova Yu. The legal basis of identification of sources and objects harmful effects of water transport Ukraine on the environment

The article focuses on the features of the impact of water transport on the environment, through the legal definition of environmentally harmful sources and objects of water transport. Based on the analysis of modern regulatory and legal regulation of environmental safety in water transport, it was found that the sphere of dangerous impact of water transport on the environment is quite extensive and includes such activities (sources) as:

1) construction, reconstruction, restoration, overhaul of marine and river ports, loading and unloading piers (except for ferry piers);

2) use, storageand transportation of harmful (dangerous) substances, dangerous goods;

3) the use of special technical means necessary for the operation of sea and river vessels, which lead to the formation of physical (electromagnetic, ionizing) effects radio centers;

4) dumping of hazardous waste.
Given this, it is established that harmful effects on water transport are created by objects that cause such effects on the environment, which are: 1) hazardous substances, waste, cargo used, formed or transported by sea and river vessels; 2) sea and river vessels; 3) water transport infrastructure facilities.

It is established that the legal regulation of such activities should be carried out within the mechanism of legal provision of environmental safety, which is defined as a set of state legal means aimed at regulating activities that can enhance environmental safety, prevent environmental degradation and endanger the population and natural systems, localization of manifestations of ecological danger.

The author concludes that the current domestic legislation on water transport needs to be improved by establishing direct legal norms on the sources and objects of harmful effects on the environment.

Key words: water transport, harmful effects, environment, source of impact, object of impact.

\section{Література}

1. Транспортне право України : навч. посіб. / Демський Е.Ф., Гіжевський В.К., Демський С.Е., Мілашевич А.В.; За заг. ред. В.К. Гіжевського, Е.Ф. Демського. K. : Юрінком Iнтер, 2002. 416 с

2. Про транспорт : Закон України від 10 листопада 1994 року. Відомості Верховної Ради України. 1994. № 51. Ст. 446.

3. Андрейцев B.I. Екологічне право: курс лекцій. Навчальнии посібник для юридичних факультетів вузів. К. : Венmypi, 1996. 207 c.

4. Андрейцев B.I. Право екологічної безпеки в Україні: проблеми об’єктного складу. Право України. 2001. № 10. C. $9-12$.

5. Про охорону навколишнього природного середовища: Закон України від 25 червня 1991 року. Відомості Верховної Ради УРСР. 1991. № 41. Cm. 546.

6. Кодекс торговельного мореплавства Украӥни від 23 травня 1995 року. 


\section{ЮРИАИЧНИЙ ВІСНИК, 2020/3}

Відомості Верховної Ради України. 1995. №.№ 47-52. Cm. 349 .

7. Ноффе О.С. Избранные труды: В 4 m. T. 1. Правоотношение по советскому гражданскому праву. Ответственность по советскому гражданскому праву СПб : Издательство «Юридический иентр Пресс», 2003. 574 с.

8. Класифікаційне товариство "Регістр судноплавства України». Регістрова книга суден.

9. Про затвердження Правил реєстраиї операцій зі икідливими речовинами на суднах, морських установках $i$ в портах України : наказ Міністерства транспорту України від 10 квітня 2001 року № 205. Офіційний вісник України. 2001. № 22. Cm. 1022 .

10.Про основні напрями державної політики України в галузі охорони довкілля, використання природних ресурсів і забезпечення екологічної безпеки : постанова Верховної Ради України від 5 березня 1998 року № 188. Відомості Верховної Ради України. 1998. № 38-39. Cm. 248 .

11. Про оцінку впливу на довкілля: Закон України від 23 травня 2017 року. Відомості Верховної Ради України. 2017. № 29. Cm. 315 .

12. Про морські порти України : Закон України від 17 травня 2012 року. Відомості Верховної Ради України. 2013. № $7 . \mathrm{Cm}$. 65 .

13. Новиков О.Н., Казакова Ю.В. Очистка подсланевых вод на судах. URL: http / / wrw.ekolog-alfa.kalg.ru/page7.html.

14. Ольга Мелень. Безпечніше судноплавство та чистіші океани. Вісник екологічної адвокатури. 2002. № 19. С. 20-24.
15. Водний кодекс України від 6 квітня 1995 року. Відомості Верховної Ради України. 1995. № 24. Ст. 189.

16. Про затвердження Правил запобігання забрудненню із суден внутрішніх водних шляхів України : наказ Міністерства транспорту та зв'язку України від 13 серпня 2007 року № 694. Офічійний вісник України. 2007. № 79. Ст. 2965.

17. Про затвердження Інструкиіi щодо проиедур прийняття та скидання водного баласту на акваторії річкових внутрішніх водних шляхів України : наказ Міністерства транспорту та зв'язку України від 13 червня 2007 року № 491. Офіиійний вісник України. 2007. № 48. Cm. 2000.

18. Про затвердження Інструкиї про порядок пломбування в морських портах суднових запірних пристроїв, призначених для скидання забруднюючих речовин $i$ вод, що їх містять : наказ Міністерства інфраструктури України від 05 грудня 2016 року № 433. Офіційний вісник України. 2017. № 4. Cm. 163.

19. Про затвердження Порядку складання паспортів річок $i$ Порядку встановлення берегових смуг водних иляхів та користування ними: постанова Кабінету Міністрів України від 14 квітня 1997 року № 347. Офіщійний вісник Украіни. 1997. № 16. Код акту 580/0/ 1997.

20.Про перевезення небезпечних вантажів : Закон України від 6 квітня 2000 року. Відомості Верховної Ради України. 2000. № 28. Cm. 22.

21. Цивільний Кодекс України від 16 січня 2003 року. Відомості Верховної Ради України. 2003. № 40-44. Сm. 356 . 